\title{
EFFECTS OF PHYSICOCHEMICAL FACTORS AND THE LOCAL ECOLOGICAL KNOWLEDGE ON THE POPULATION OF HELICOSTYLA DAPHNIS (BRODERIP, 1841) IN BORBON AND SOGOD, CEBU, PHILIPPINES
}

\author{
FUNESTO, E. G. M. ${ }^{*}-$ FLORES, M. J. L. \\ Department of Biology and Environmental Science, College of Science, University of the \\ Philippines Cebu, Cebu City 6000, Philippines \\ *Corresponding author \\ e-mail: emfunesto@up.edu.ph \\ (Received 29 $9^{\text {th }}$ Dec 2016; accepted $27^{\text {th }}$ Apr 2017)
}

\begin{abstract}
Helicostyla daphnis (Broderip, 1841), an arboreal edible snail endemic to Cebu, Philippines that was thought to be extinct, was discovered to be still thriving. To formulate strategies for conservation of H. daphnis, a survey of selected physicochemical parameters and local ecological knowledge (LEK) that could affect its population was conducted. On each the three sites, physicochemical parameters were measured and a standardized direct search method for snails was used. LEK was gathered among fifteen snail-hunting experts. Snail total abundance significantly varied across sites in the dry season $(p=0.006)$, being highest at Site 1(private property), and least in at Site 2 (tree plantation). Snails were found to be more abundant in the dry season than the wet $(\mathrm{dry}=306$; wet=152) but significant only at Site 1 . Adult snails were the most dominant among the age categories in both the dry and wet seasons. Neonates, comprising 5\% of the sampled population, were found only in the wet season. Relative humidity and air temperature were the major determinants of the total abundance. However LEK gathered pointed out that overharvesting and habitat destruction could be major contributors as well. Ficus leucantatoma, Buchananiaar borescens and Artocarpus heterophyllus are the vegetation most prefered by $H$. daphnis, according to LEK.
\end{abstract}

Keywords: LEK, takyong, conservation, land snail

\section{Introduction}

Invertebrates make up nearly 99\% of animal diversity (Pechenik, 2014). Unfortunately, many of these invertebrates are already extinct or endangered (Pimm et al., 2014). Studying invertebrates have less publicity, and thus, fewer scientists are attracted to do research on them. One of the most ignored groups of animals among the invertebrates is the non-marine mollusk. These mollusks play an important role in the mobilization of calcium to higher trophic levels. They are also involved in the plant litter decomposition process, as most of the species are considered to be consumers of decaying plant materials including microbial decomposers such as fungi and bacteria. Despite the important functions non-marine mollusks have in the ecosystem, they and other mollusks have suffered from extinction, and little efforts have been done to conserve them. In the IUCN List of Threatened Species in 2016, 6,033 gastropods are listed (IUCN, 2016).

Helicostyla daphnis (Fig. 1) locally known as "takyong", is an endemic land snail in Cebu, Philippines. The book Endangered Wildlife and Plants of the World (2001) stated that these landsnails was known only from the rain forests near Cebu Island in the Philippines. It was further stated that destruction of the rainforests by agriculture and the logging industry has had a serious impact on this tree snail. In 2001, Helicostyla 
daphnis was reported to be extinct (Coney, 2001). However, in 2010, there were reports of the presence of these snails in Borbon, one of the municipalities of Cebu. When some faculty members of the University of the Philippines Cebu did an investigation, it was found out that these snails are sold commercially, consumed as food, and harvested for the making of accessories.

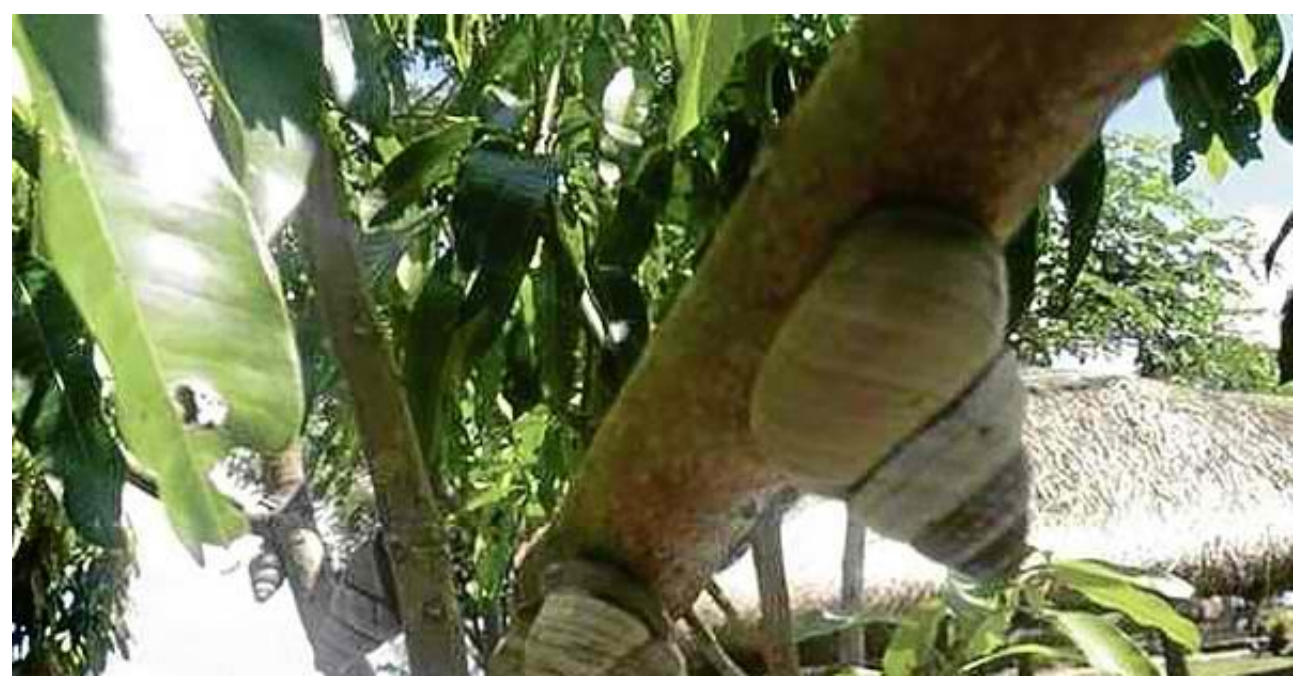

Figure 1. Helicostyla dapnhnis attached on a tree.

In Borbon, 'takyong' is considered as a delicacy. In 2011, these snails served as an entry to Obra Negosyo, a program that encouraged entrepreneurship development in the province. The snail was rumored to have therapeutic effects to those who have asthma and allergies. Local folks claim that when they eat 'takyong' they are relieved of their respiratory and allergy-related ailments, and the meat seemed to be a good source of energy and stamina. Some even consider it an aphrodisiac (Garces, 2011).

The reports of these land snails' extinction have urged the local government to regulate their harvest (Garces, 2011). However, currently, there is very limited information about these land snails. Based on the principles of environmental conservation, to effectively protect a certain species of animal or plant, an adequate amount of knowledge is necessary to design effective conservation programs. There is then a need then to fill in this gap of knowledge. To address this issue, this study tried to find out the effects of physicochemical factors like relative humidity, $\mathrm{pH}$, elevation, air temperature, and soil calcium on the population of $H$. daphnis. This study also tried to collect the local ecological knowledge on the biology and ecology of H. daphnis.

\section{Materials and Methods}

\section{The study site}

This study was done in three sampling sites. The sites (Fig. 2) were selected according to local knowledge on where the snails were collected for consumption. Three $20 \mathrm{~m}$ x $20 \mathrm{~m}$ quadrats that represented the plots were placed randomly at each site. 


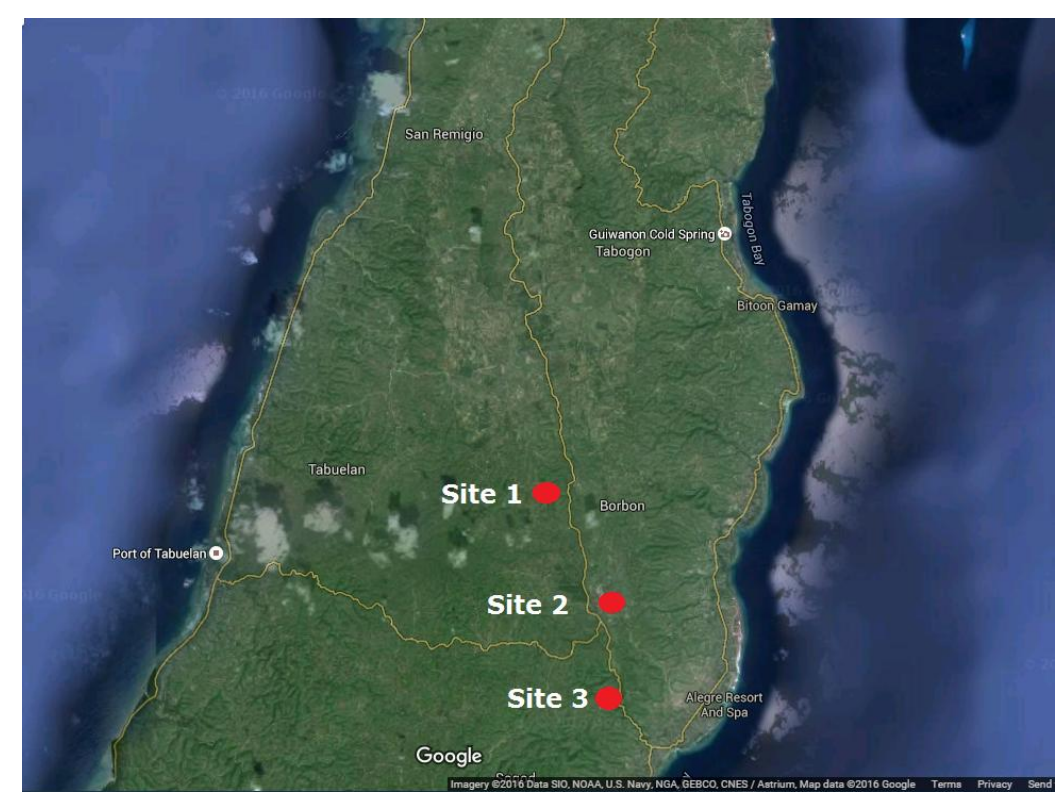

Figure 2. Map showing Site 1 (Barangay Cajel), Site 2 (Barangay Lugo) and Site 3 (Barangay Liki) where the study was done (image from Google Earth).

Site 1, had coordinates of $10^{\circ} 49^{\prime} 30.9^{\prime \prime} \mathrm{N}, 123^{\circ} 57^{\prime} 12.9^{\prime \prime} \mathrm{E}$ and an elevation of 184 masl. It had secondary growth vegetation. Site 2 had coordinates $10^{\circ} 49^{\prime} 11.1^{\prime \prime N}$, $123^{\circ} 59^{\prime} 9.4^{\prime \prime} \mathrm{E}$ and an elevation of 265 masl. Since it was a tree plantation site, it was dominated by two tree species: Leucaena leucocephala and Cocos nucifera L. Site 3 had coordinates of $10^{\circ} 47^{\prime \prime} 56.9^{\prime \prime} \mathrm{N}, 123^{\circ} 59^{\prime} 35.6 " \mathrm{E} "$ at 132 masl (Plot 1) and $10^{\circ} 47^{\prime} 23.0^{\prime \prime} \mathrm{N}, 123^{\circ} 59^{\prime} 47.9^{\prime \prime}$ at 148 masl (Plots 2 and 3). It had a steep slope and a dominant thick ground cover of Cogon grasses and shrubs.

\section{Physicochemical and biological survey}

Methods by de Chavez and de Lara (2011) adopted from Schilthuizen and Rutjes (2001) were used. The physicochemical factors (elevation, air temperature, relative humidity, top soil $\mathrm{pH}$, soil exchangeable calcium) in all study sites were collected in replicates of three. A hand-held Global Positioning System was used to know the geographic coordinates and elevation of each sampling site. A field thermometer was suspended for at least $5 \mathrm{~m}$ above the ground to take note of the air temperature. To measure relative humidity, a hand-held sling psychrometer was used. Approximately 500 grams of topsoil was collected from three points in each quadrat. The soil samples were air-dried, then brought to a soil laboratory for analysis of soil exchangeable calcium. For the measurement of $\mathrm{pH}$, a $\mathrm{pH}$ meter was used.

For each quadrat, people conducting the survey searched for live snails equivalent to a two-hour sampling effort. The number of $H$. daphnis individuals found in each quadrat was accounted for the species abundance for that quadrat. The sampling was done twice in a year, once during the dry season and once during the rainy season, between 0600-0900 $\mathrm{h}$ and/or from 1600-1800 $\mathrm{h}$. 


\section{Gathering of local ecological knowledge}

Participants for the local ecological knowledge survey were determined following the method suggested by Davis and Wagner (2003). A list of ten snail hunters was solicited from the local officials of the three barangays. Each snail hunter on the list were asked the following questions:

1. "Other than yourself, who would you say knows the most about 'takyong' (Helicostyla daphnis)?

2. Are there any other persons who you think are very knowledgeable about 'takyong' (Helicostyla daphnis)'?

At least five names were solicited for each snail hunter interviewed. The names of people mentioned by the snail hunters were then ranked-ordered based on the frequency of mentions. The top five names from each barangay are the ones considered as the "experts" from which local ecological knowledge was taken. The fifteen experts (five for each site) were then subjected to in-depth, face-to-face interviews.

The objectives of the project were presented and discussed before the data collection. Each key informant was interviewed following a semi-structured conversation. All encounters were audio recorded with previous consent from informants. The knowledge claim should be mentioned at least three times by the experts for it to be considered acceptable. Conversations were freely conducted, giving opportunity for the deeper exploration of the informant's knowledge, with the following pre-determined topics:

o medicinal effect

$\circ$ vegetation preference

o diet

○ life cycle

$\circ$ hunting practices and consumption

\section{Analyses of data}

The physicochemical and biological variables were analyzed using Statistical Package for Social Sciences (SPSS) Version 22 (trial version). To determine the significance of the relationship of more than two variables (e.g., physicochemical parameters at the different sites during the different seasons), the one-way Analysis of Variance (ANOVA) and independent t-test were used. Pearson Correlation Analysis was also used to determine the magnitude (significant or strongly significant) and direction (negative or positive) of the relationship between variables (e.g., abundance and certain physicochemical variable).

\section{Results}

\section{Physicochemical parameters and snail abudance between sites and seasons}

Tables 1 and 2 show the mean physicochemical parameters and abundance of Helicostyla daphnis in the dry season and wet season respectively, and also the level of significant difference between the three sites. 
Table 1. The mean \pm standard error and level of significance of each physicochemical parameter and Helicostyla daphnis abundance for each age category by site in the dry season.

\begin{tabular}{lcccc}
\hline \hline & Site 1 & Site 2 & Site 3 & Sig. \\
\hline Relative Humidity $(\%)$ & $81.33+3.32$ & $67.00+3.77$ & $77.44+3.91$ & $0.000^{*}$ \\
pH & $7.56+0.28$ & $8.49+0.24$ & $8.52+0.32$ & $0.000^{*}$ \\
Elevation (masl) & $184.00+0.00$ & $265+0.00$ & $142+8.00$ & $0.000^{*}$ \\
Air Temperature $\left({ }^{\circ} \mathbf{C}\right)$ & $32.97+1.36$ & $30.38+1.24$ & $28.81+1.00$ & $0.000^{*}$ \\
Soil Calcium $(\mathbf{m g} / \mathbf{g})$ & $0.48+0.41$ & $106.55+27.36$ & $12.36+4.13$ & $0.000^{*}$ \\
Juvenile & $2.11+2.93$ & $0.89+1.27$ & $3.44+4.00$ & 0.207 \\
Adult & $19.56+15.99$ & $2.00+1.73$ & $6.00+6.91$ & $0.003^{*}$ \\
Neonate & - & - & - & - \\
Total & $21.67+17.55$ & $2.89+2.03$ & $9.44+8.52$ & $0.006^{*}$ \\
Eggs & - & - & - & - \\
\hline \hline
\end{tabular}

*The mean difference is significant at the $\mathrm{p}<0.05$ level (One-way ANOVA).

Table 2. The mean \pm standard error and level of significance of each physicochemical parameter and Helicostyla daphnis abundance for each age category by site in the wet season.

\begin{tabular}{lcccc}
\hline \hline & Site 1 & Site 2 & Site 3 & Sig. \\
\hline Relative Humidity $(\%)$ & $70.67 \pm 9.38$ & $66.78 \pm 2.22$ & $66.00 \pm 1.58$ & 0.192 \\
pH & $7.71 \pm 0.32$ & $7.91 \pm 0.21$ & $8.08 \pm 0.22$ & $0.019^{*}$ \\
Elevation (masl) & $183.00 \pm 0.00$ & $265 \pm 0.00$ & $142.67 \pm 8.00$ & $0.000^{*}$ \\
Air Temperature $\left({ }^{\circ} \mathbf{C}\right)$ & $26.11 \pm 1.45$ & $25.78 \pm 0.83$ & $27.22 \pm 1.09$ & $0.035^{*}$ \\
Soil Calcium $(\mathbf{m g} / \mathbf{g})$ & $38.25 \pm 10.98$ & $55.03 \pm 20.19$ & $61.27 \pm 24.91$ & 0.695 \\
Juvenile & $3.33 \pm 3.42$ & $1.22 \pm 1.30$ & $1.89 \pm 2.93$ & 0.26 \\
Adult & $4.11+3.18$ & $0.89+1.36$ & $3.22+6.78$ & 0.293 \\
Neonate & $0.56+1.33$ & $0.00+0.00$ & $0.78+1.56$ & 0.374 \\
Total & $8.00+5.19$ & $2.11+1.90$ & $6.78+10.47$ & 0.178 \\
Eggs & - & - & - & - \\
\hline \hline
\end{tabular}

*The mean difference is significant at the $\mathrm{p}<0.05$ level (One-way ANOVA).

Tables 3-5 show the mean physicochemical parameters and snail abundance for each site, comparing the dry and wet season, and showing the level of significant difference between the seasons.

Table 3. The mean \pm standard error and level of significance of each physicochemical parameter and Helicostyla daphnis abundance for each age category by season in Site 1.

\begin{tabular}{lccc}
\hline \hline & Dry & Wet & Sig. (2-tailed) \\
\hline Relative Humidity $(\boldsymbol{\%})$ & $81.33+3.32$ & $70.67+9.38$ & $0.005^{*}$ \\
pH & $7.57+0.28$ & $7.71+0.32$ & 0.32 \\
Air Temperature $\left({ }^{\circ} \mathbf{C}\right)$ & $32.97+1.14$ & $23.11+1.45$ & $0.000^{*}$ \\
Soil Calcium $(\mathbf{m g} / \mathbf{g})$ & $0.48+0.41$ & $38.26+32.94$ & $0.003^{*}$ \\
Juvenile & $2.11+2.93$ & $3.33+3.43$ & 0.428
\end{tabular}




\begin{tabular}{lccc} 
Adult & $19.56+15.99$ & $3.17+1.06$ & $0.012^{*}$ \\
Neonate & $0.00+0.00$ & $0.56+1.33$ & 0.229 \\
Total & $21.67+17.55$ & $8.00+5.20$ & $0.040^{*}$ \\
Eggs & $0.00+0.00$ & $2.00+6.00$ & 0.332 \\
\hline
\end{tabular}

*The mean difference is significant at the $\mathrm{p}<0.05$ level (Independent sample $\mathrm{t}$-test).

Table 4. The mean \pm standard error and level of significance of each physicochemical parameter and Helicostyla daphnis abundance for each age category by season in Site 2.

\begin{tabular}{lccc}
\hline \hline & Dry & Wet & Sig. (2-tailed) \\
\hline Relative Humidity $(\%)$ & $67.00+3.77$ & $66.78+2.22$ & 0.881 \\
Ph & $8.49+0.24$ & $7.91+0.21$ & $0.000^{*}$ \\
Air Temperature $\left({ }^{\circ} \mathbf{C}\right)$ & $30.38+1.24$ & $25.78+0.83$ & $0.000^{*}$ \\
Soil Calcium $(\mathbf{m g} / \mathbf{g})$ & $106.55+27.36$ & $55.03+60.56$ & $0.034^{*}$ \\
Juvenile & $0.89+1.27$ & $1.22+1.30$ & 0.59 \\
Adult & $2.00+1.73$ & $0.89+1.37$ & 0.15 \\
Neonate & - & - & - \\
Total & $2.89+2.03$ & $2.11+1.90$ & 0.413 \\
Eggs & - & - & - \\
\hline \hline
\end{tabular}

*The mean difference is significant at the $\mathrm{p}<0.05$ level (Independent sample t-test).

Table 5. The mean \pm standard error and level of significance of each physicochemical parameter and Helicostyla daphnis abundance for each age category by season in Site 3.

\begin{tabular}{lccc}
\hline \hline & Dry & Wet & Sig. (2-tailed) \\
\hline Relative Humidity $(\%)$ & $77.44+3.91$ & $66.00+1.58$ & $0.000^{*}$ \\
pH & $8.52+0.32$ & $8.08+0.22$ & $0.003^{*}$ \\
Air Temperature $\left({ }^{\circ} \mathbf{C}\right)$ & $28.81+1.00$ & $27.22+1.09$ & $0.005^{*}$ \\
Soil Calcium $(\mathbf{m g} / \mathbf{g})$ & $12.36+4.13$ & $61.27+74.72$ & $0.068^{*}$ \\
Juvenile & $3.44+4.00$ & $1.89+2.93$ & 0.361 \\
Adult & $6.00+6.91$ & $4.11+6.83$ & 0.568 \\
Neonate & $0.00+0.00$ & $0.78+1.56$ & 0.155 \\
Total & $9.44+8.52$ & $6.77+10.47$ & 0.562 \\
Eggs & 0 & 0 & - \\
\hline \hline
\end{tabular}

*The mean difference is significant at the $\mathrm{p}<0.05$ level (Independent sample $\mathrm{t}$-test).

\section{Snail count}

Figure 3 shows a total abundance of 306 snails during the dry season, with the highest count of 195 individuals at Site 1 and the lowest count of 26 at Site 2. There were no neonates, but there were 58 juveniles and 248 adults. 


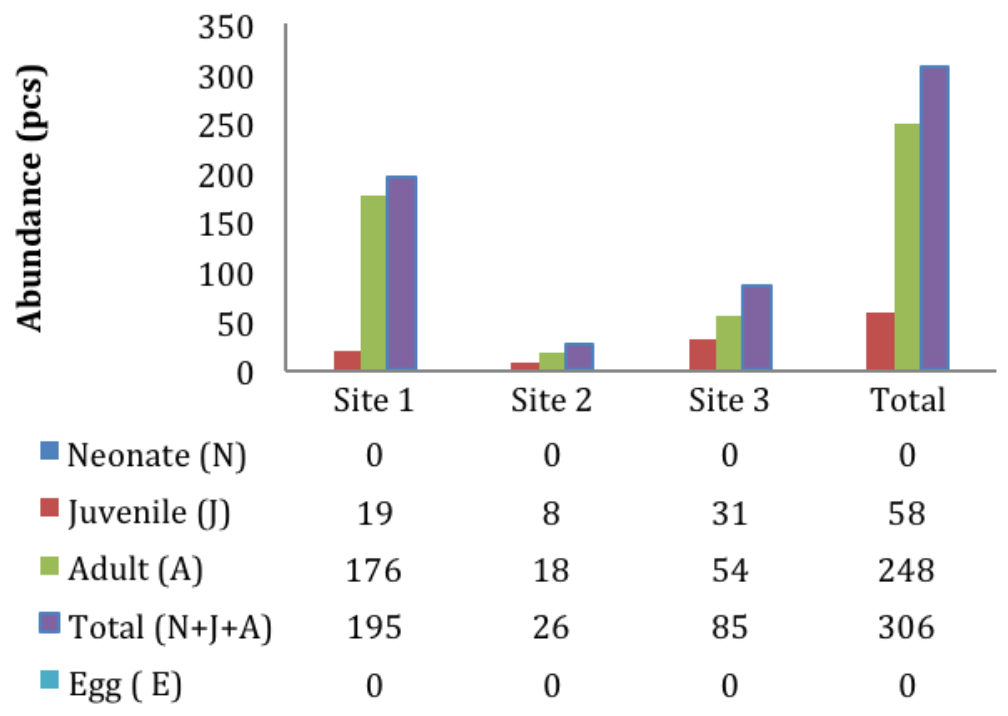

Figure 3. The abundance of Helicostyla daphnis in the dry season, by age category (neonate, juvenile, adult, egg), and location (Site 1, Site 2 and Site 3).

A total abundance of 152 was recorded during the wet season (Fig. 4). There were 5 neonates, 58 juveniles, and 82 adults. Site 1 still had the highest total count of 72 individuals, and Site 2 the lowest with 19 individuals. Total abundance was only significantly different between sites in the dry season, $(\mathrm{p}=0.006)$ and between seasons in Site $1(\mathrm{p}=0.040)$.

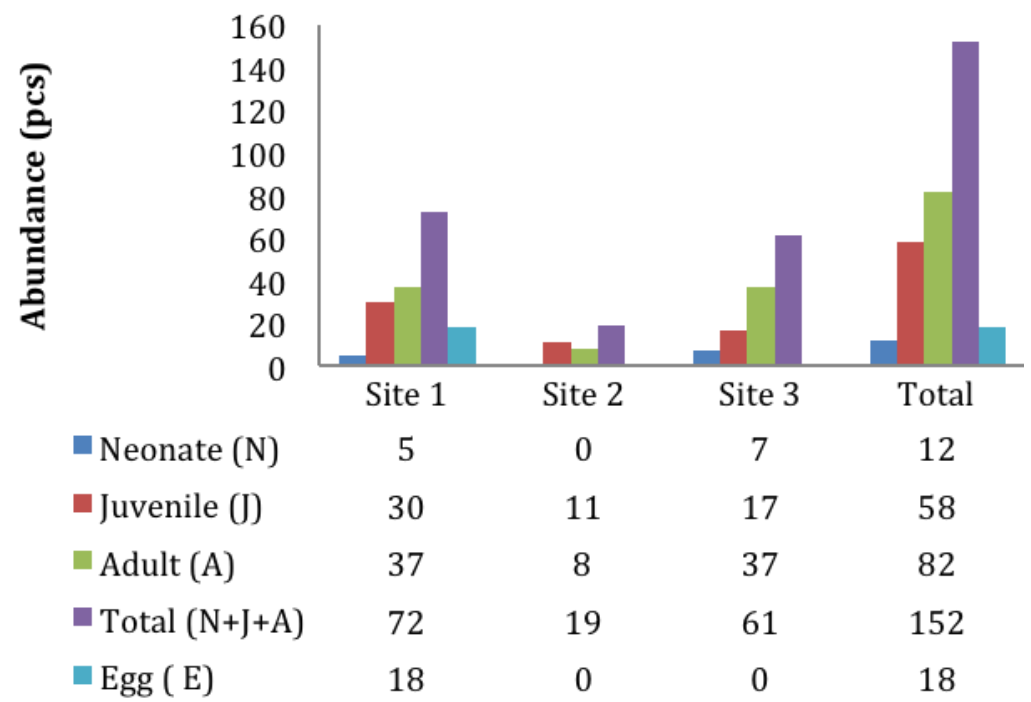

Figure 4. The abundance of Helicostyla daphnis in the wet season, by age category (neonate, juvenile, adult, egg), and location (Site 1, Site 2 and Site 3).

Five neonates were found at Site 1 and seven at Site 3 in the wet season but none in the dry season. During the dry season, the highest number of juvenile snails was found at Site 3, while the least was found at Site 2. Adult snails were most numerous at Site 1 during the dry season, and least at Site 2 in the wet season. The total abundance, 
accounting the neonate, juvenile and adult snails, was highest at Site 1 during the dry season and lowest at Site 2 during the wet season. Eggs of $H$. daphnis were found only at Site 1 during the wet season.

\section{Population composition}

The composition of $H$. daphnis by age category and by season is shown in Figure 5. The adult snails comprised $81 \%$ of the total snail population in the dry season, and $70 \%$ in the wet season. The adult population varied significantly across sites only in the dry season $(\mathrm{p}=0.003)$ and across seasons only in Site $1(\mathrm{p}=0.040)$. Juveniles comprised 19\% of the sampled population during the dry season, and $25 \%$ during the wet season. The presence of juveniles did not vary significantly across sites and between seasons. Neonate snails, although variation was insignificant, were absent during the dry season, but comprised $5 \%$ of the sampled population in the wet season.

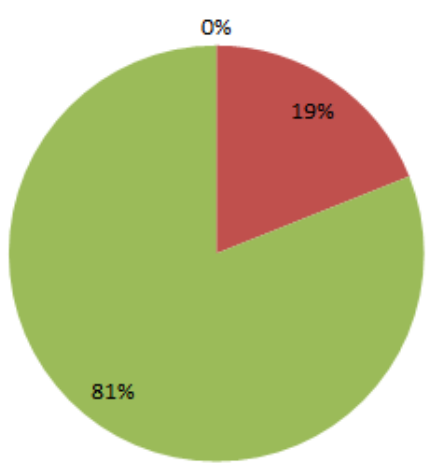

a

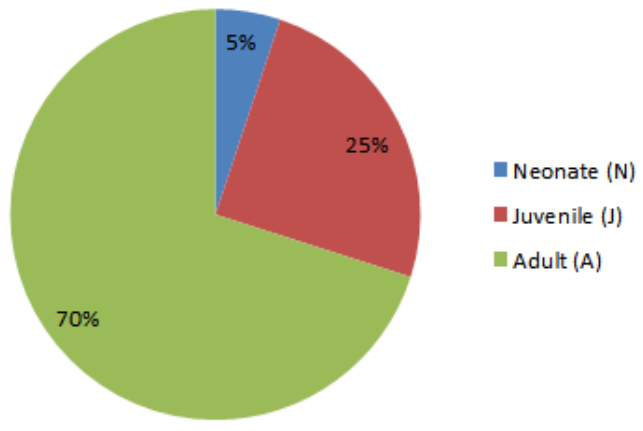

b

Figure 5. Population profile of Helicostyla daphnis in Borbon and Sogod, Cebu during the dry (a) and wet (b) season.

Table 6 shows that juvenile abundance and total abundance in Site 1 is positively correlated with relative humidity $(\mathrm{r}=0.615$ and 0.556 , respectively; $\mathrm{p}<0.01$ and $<0.05$, respectively). Adult abundance and total abundance is positively correlated with air temperature ( $\mathrm{r}=0.643$ and 0.547 , respectively; $\mathrm{p}<0.01$ and $<0.05$, respectively). Neonate abundance and egg abundance is positively correlated with soil calcium ( $\mathrm{r}=0.488$ and 0.527 , respectively; $\mathrm{p}<0.05)$. There was no correlation found in snail abundance and physicochemical parameters in Site 2 and Site 3.

Table 6. Pearson correlation coefficient between selected physicochemical factors and abundance of $H$. daphnis at the egg, neonate, adult stages, and with total abundance, by site.

\begin{tabular}{|c|c|c|c|c|c|c|c|c|c|c|c|c|c|c|c|}
\hline Site & \multicolumn{3}{|c|}{ Juvenile } & \multicolumn{3}{|c|}{ Adult } & \multicolumn{3}{|c|}{ Neonate } & \multicolumn{3}{|c|}{ Total } & \multicolumn{3}{|c|}{ Egg } \\
\hline $\begin{array}{l}\text { Relative } \\
\text { Humidity }\end{array}$ & - & - & - & $.615^{* *}$ & - & - & - & - & - & $556 *$ & - & - & - & - & - \\
\hline $\mathrm{pH}$ & - & - & - & - & - & - & - & - & - & - & - & - & - & - & - \\
\hline Elevation & - & - & - & - & - & - & - & - & - & - & - & - & - & - & - \\
\hline Soil Calcium & - & - & - & - & - & - & $488 *$ & - & - & - & - & - & $527 *$ & - & - \\
\hline
\end{tabular}

* Correlation is significant at the 0.05 level (2-tailed). 


\section{Local ecological knowledge}

\section{Medicinal effect}

According to the experts, asthma, arthritis, and body pains can be cured by consuming $H$. daphnis. Four snail hunters claimed to have had a first-hand experience of being alleviated from the mentioned illnesses, but the rest said they have only heard about it.

When asked how the snail was prepared to serve as medicine, the experts gave several procedures:

- The snails are roasted in open fire and then consumed.

- Live snails are soaked in water overnight. The water where the snail was soaked is then drunk.

- Snails are boiled. After boiling, the water used to boil the snails is then applied to the affected/painful body part.

\section{Life cycle and seasons}

H. daphnis does not follow any trend or season when laying eggs. Eggs are seen throughout the year. The following is the life cycle of $H$. daphnis according to the experts:

1. Adult $H$. daphnis when ready to lay eggs rolls a leaf around its body to cover itself from surroundings and to protect its eggs.

2. An average of a hundred eggs is laid inside the rolled leaf. The eggs are at first covered in mucus-like liquid, and then later on this liquid hardens.

3. After laying the eggs, the adult snail would detach from the leaf and leave behind its' eggs.

4. The eggs would hatch at around two weeks after they are laid.

5. Small snails then crawl their way out of the leaf that had covered them, and would mature into adult snails.

\section{Vegetation preference}

Table 7 shows a listing of the all the plants the snails preferred as observed by the snail hunters. Mentioned at least three times by snail hunters were ' lagnog' (Ficus leucantatoma', 'an-an' (Buchananiaar borescens) and 'nangka' (Artocarpus heterophyllus).

Table 7. Vegetation identified by experts where Helicostyla daphnis could be found.

\begin{tabular}{clcc}
\hline \multicolumn{2}{l}{ Common Name } & Scientific Name & Type \\
\hline 1. & agusahis & Ficus septica (Blanco) & Tree \\
2. & an-an & Buchananiaar borescens (Blume) & Tree \\
3. & anugas & Semecarpus cuneiformis (Blanco) & Tree \\
4. & awm & Macaranga sp. & Tree \\
5. & bagalnga & Melia dubia (Cav.) & Tree \\
6. & bagisang & Tree \\
7. & bagon-bagon & Vine \\
8. & basil nga kahoy & Cissampelos pareira $($ L. $)$ & \\
9. & bukawi & &
\end{tabular}




\begin{tabular}{|c|c|c|c|}
\hline 10. & bunot-bunot & Glochidion camiguinense (Merr.) & Tree \\
\hline 11. & dakit & Ficus benjamina (L.) & Tree \\
\hline 12. & gabugnaw & & \\
\hline 13. & hagunoy & Chromolaena odorata (L.) & Shrub \\
\hline 14. & hagupit & & \\
\hline 15. & marabilis & Lantana camara (L.) & Tree \\
\hline 16. & lagnog & Ficus leucantatoma (Merr) & Tree \\
\hline 17. & lagumo & & \\
\hline 18. & lobi & Cocos nucifera (L.) & Tree \\
\hline 19. & lobi-lobi & Ficus pseudopalma (Blanco) & Tree \\
\hline 20. & nangka & Artocarpus heterophyllus (Lam.) & Tree \\
\hline 21 . & putian na dahon & Alangium javanicum (Blume) & Tree \\
\hline 22. & saa & Mallotus philippinensis (Lamk.) Muell. Arg. & Tree \\
\hline 23. & tsaa & & \\
\hline 24. & tuwa-tuwa & Jatropha curcas (L.) & Tree \\
\hline
\end{tabular}

\section{Diet}

Experts mentioned leaves, bark of trees, morning dew, or sap as the diet of $H$. daphnis. Experts think that through eating leaves, bark of trees, or sap, the H.daphnis can acquire the healing properties of the plants. Some experts mentioned morning dew because they have observed that no leaf damage is present in plants wherein these land snails dwell in.

\section{The change in snail population and body size in the last five years}

The population of the snails has decreased as perceived by the experts. According to them, this could be due to the increase in the number of people that are hunting for snails, as well as the increased frequency of typhoons. There was no change in body size as perceived by the experts.

\section{Consumption of snails}

The following are the reasons for consumption of $H$. daphnis as food:

- It can heal their sicknesses (asthma and/or arthritis).

- Their elders have passed on this custom.

- They eat it as viand.

- Gives them energy.

Local people would cook the snails in several ways, much like how they cook other meat. Here are some of the dishes mentioned:

- Piniritong takyong (fried 'takyong')

- Tortang takyong ('takyong' omelet)

- Sinabawang takyong ('takyong soup')

- Sinugbang takyong (grilled 'takyong')

- Halang-halang (spicy sautéed 'takyong') 


\section{Harvesting practices}

Harvesting of snails is done using bare hands or with the use of a stick. However if none of these works, they would resort to shaking the tree until the snails fall to the ground.

Hunting is done mostly in the wet season when the land is cool and snails would go to lower places. In the dry season, the snails tend to go up to higher places to escape from the heat emitted by the ground.

Hunting is preferably done in the morning between 0700-1000 hours when the air temperature is still relatively cooler. Hunting is done for an average of 2-3 hours. Hunting in the wooded areas when it is already hot was more tiring. Also, the snails tend to go to the upper parts of the tree when the land is too hot, hence more difficult to get.

Although the hunters do not choose the snails when they hunt, they tend to leave behind the small ones to give them time to grow and reproduce.

\section{Harvesting trend}

The average number of snails that are harvested by the snail hunters is 45 snails per hour. The majority of the experts said that there is no change in the trend of harvest.

Most of the snail hunters interviewed would harvest snails for the sole purpose of eating them. They think that it is a waste to sell the snails because the snails are sold at a very cheap price $(0.020 \mathrm{USD} /$ piece), considering the time and effort exerted hunting for them. However, three of the experts concurred that they sell the snails. The number of the snails they sell would depend on the number of snails harvested.

\section{Human activities that affect the population of the snails}

The following are human activities that snail hunters have observed to affect the population of snails:

- Frequent harvesting of snails without giving time for the population to regenerate.

- Harvesting of the small snails and eating them.

- Getting the eggs of the snails.

- Cutting off the trees that serve as habitat of snails especially when they are found in the uppermost branches during harvest.

- Cutting the trees they dwell in to be used as fuel wood

\section{Discussion}

Total abundance of Helicostyla daphnis was generally higher during the dry season than the wet season especially at Site 1 (Tables 1 and 3). Of the age categories, adult and juvenile snails were present in all sites in both seasons; while eggs only at Site 1 and neonates only at Site 1 and 3 during the wet season. Adult snails dominated the sites in both seasons with significant variation between sites only in the dry season; variation was significant between seasons only at Site 1. Meanwhile, relative humidity, air temperature, and soil exchangeable calcium showed significant correlation with the abundance of at least one of the age categories and/or with the total abundance of the snails. Relative humidity and air temperature seemed to be the major predictors of snail 
abundance as these significantly correlated with total abundance, and highly with adult abundance. Soil exchangeable calcium, on the other hand, correlated significantly with neonates and eggs.

The high snail abundance during the dry season especially at Site 1 could be because of the high relative humidity and air temperature during this season. Furthermore, Site 2 is a flatland and was the most accessible of all the sites as it is located beside the highway, and this could account for the very low snail abundance on this site. The relatively high snail abundance during the dry season compared with the wet season could also be due to the harvesting practices by the local people. As revealed by the snail hunting experts in LEK gathering, the wet season is the time preferred by locals to hunt for snails because the land is cool so the snails would move to lower places. In the dry season, the snails tend to go up to higher ground to escape the heat emitted by the ground. This claim by snail experts matches with the reports of Hunter and his colleagues (2013). They reported that snails hide at daytime by moving up to vegetation when they are prone to desiccation.

Environments with high relative humidity are desirable. In Moreno-Rueda's (2014) study on two species of landsnail, S. candidissima and I. gualterianus, there was a concave-upward relationship between moisture and abundance in arid environments. One of the reasons for this relationship according to Moreno-Rueda is that high moisture is associated with abundant vegetation. Land snails rely on vegetation as their source of food. However, he pointed out that moisture could be a limiting factor for abundance because high moisture is also associated with high abundance of predator and parasites (Moreno-Rueda, 2014). In a more recent study on the Giant African snail (Achatina fulica (Bowdich, 1822)) in South Florida USA, more land snails were found in time with high humidity (Roda et al., 2016).

Another environmental factor contributing to the abundance of land snail population is air temperature. Air temperature is positively correlated with adult and total snail abundance of $H$. daphnis base on the results of this study (Table 6). In literature, one would find that abundance of land snails in response to temperature varies depending on the species of snails. Nunes and Santos (2012), investigated the environmental factors that affect the species distribution of land snails in Brazil. They found out that atmospheric temperature, among others is a major factor in determining the speciescompositional variation of land snails between two mountains.

Horsak et al. (2014), found that abundance and diversity of land snails is positively correlated with calcium carbonate availability. Shelled gastropods strongly depend on calcium (Ca) as a major macronutrient constituent of their body (Pechenik, 2014). Aside from being a component of the shell, $\mathrm{Ca}$ is important in the metabolism in soft tissues, and reproduction (Baur et al., 2009). The mortality rate is increased and egg production is disabled in snails deprived of calcium (Johnson, 2011). The absence of correlation between juvenile and adult snails and soil calcium in this study, could be because $H$. daphnis are truly arboreal and dwell in trees in its full life cycle (Flores, 2014). This means $H$. daphnis does not get the calcium for its needs directly from the soil, as opposed to species that can absorb calcium from soil directly through their foot (Thorp and Rogers, 2016). Other snails get calcium from their surrounding in different methods, reliant on their niche. They feed on both live and dead leaves and wood, algae and fungi attached on the surfaces of rocks and wood, sap, animal carcasses, worms, and other snails (Hottop, 2014). The snail hunters interviewed during the local ecological knowledge gathering mentioned that they never saw the snails crawl on the 
ground. On this note, the 'takyong' could have gotten their calcium needs from calcium in soluble citrate form, transported directly from soil solution through the leaves or algae in leaves and bark of plants they consume.

Although soil $\mathrm{pH}$ was shown in this study to have varied significantly across sites and seasons, there was no significant relationship between $\mathrm{pH}$ and abundance of land snails. This did not coincide with the results of Horsak et al. (2014), where snail abundance was found to be positively correlated with $\mathrm{pH}$. The insignificant relationship of abundance with $\mathrm{pH}$ might be because $\mathrm{pH}$ ranged from 7.71 to 8.08 in this study, which was basic throughout sites and in both seasons. Land snails tend to prefer basic soils. Soil $\mathrm{pH}$ has a strong relationship with soil calcium. Basic soils have higher calcium and acidic soils have less calcium.

Elevation varied significantly across sites in this study, but there was no significant relationship between elevation and abundance of land snails. In 2011, Gilbert and colleagues studied the diversity and abundance of snails from 100 meters to 1700 meters in altitude and found that the highest abundance in snail families was at midaltitude (850 meters in altitude) and the highest diversity was at lowest altitude. Gilbert et al.'s (2011) study indicates a correlation, not only between snail abundance and diversity with altitudinal gradient but also between abundance and diversity with niche availability. The study sites for this research were between 142-265 masl and the highest total abundance was found at 184 masl. Considering the highest peak of Cebu to be at 1000 masl, the study sites then are located at low altitudes. However, this does not give a conclusive data on the relationship of $H$. daphnis' abundance with elevation. Further studies to validate this observation need to be done for elevations above 265 masl.

The dominance of adult snails, followed by juveniles, in all sites and in both seasons could be because adult land snails are less vulnerable to high temperature and/or low humidity since only little body surface area is exposed to the atmosphere. The bigger the snails, the less the surface area exposed to the atmosphere, hence larger snails are less vulnerable to desiccation (Chukwuka et al., 2014). Juvenile and neonate snails are more vulnerable to desiccation because they have a higher surface area exposed to the atmosphere. Another possible reason for the abundance of adult snails is that the researchers more easily see them during sampling because of their bigger body size. Meanwhile, the juveniles, neonates and eggs are more inconspicuous (Flores, 2014).

The snail hunters thought that $H$. daphnis is important to their family because it serves as a free and nutritious alternative food for local people every time they do not have the resources to buy food. Poverty could be viewed then as one of the driving forces for people in North Cebu to consume H. daphnis. Another importance pointed out by snail hunters was that $H$. daphnis can cure asthma, arthritis, and body pains. At present, there are no studies that can prove the validity of this claim. However, in 2014, Bensig et al. studied the antibacterial properties of $H$. daphnis, and found out that both the tissue composite and shell methanolic extracts of $H$. daphnis were able to inhibit the growth of four tested bacterial species (Bacillus subtilis, Escherichia coli, Pseudomonas aeruginosa and Staphylococcus aureus). According to Bensig and her colleagues, the antibacterial properties could have been because of the mucus secreted by the snails, which is composed of lysozymes, opsonines, and glycoproteins. Glycoproteins are believed to lyze bacterial cytoplasmic membrane during log phase, so does penicillin (Bensig et al., 2014). According to Bensig, this could have been the probable reason for the claimed health benefits of $H$. daphnis. Interestingly one of the snail hunters 
interviewed claimed that every time she felt sick, she would soak a live 'takyong' overnight in water. The next day she would drink the water containing a concentration of the snail's mucus to make her feel better. This practice, however, might be harmful to human health. It might bring in unwanted parasites and infections since the snail is not cooked. An example is a disease called Angiostongyliasis, an infection caused by a nematode from the genus Angiostrongylus. This infection can occur after eating raw infected snails or slugs (Yeung et al., 2013).

The $H$. daphnis is sold at one peso (0.020 USD) per piece. The snail hunters think this price is cheap considering the energy and effort given in hunting the snails in the forest. Helix escargot, which is the best-known edible snail, is sold at $\$ 0.50$ to $\$ 1$ per snail. Computing for the real cost of $H$. daphnis should include not only the cost of labor in harvesting the snail but also its environmental cost. Environmental cost includes the disruption of the chemical cycling participated by these snails, as well as the food chain and its effects on the other organisms within the ecosystem. This would need an in-depth valuation of resources.

The forested areas in the barangays are mostly government-owned; hence, anyone can freely hunt snails without limit. The snail population then is a "common," or shared resource where use/access is not formally regulated. When asked what conservation programs can the snail hunters suggest to the government, they thought that the harvesting of the snails should be under some rules that would limit the amount or the season at which 'takyong' are harvested. However, no such law exists in their barangay at present.

In the life cycle of $H$. daphnis, snail hunters interviewed said that they can find eggs all throughout the year. Being a tropical land snail, H.daphnis can exhibit continuous reproduction because of its non-seasonal habitat, in contrast with temperate species that must concentrate reproduction in one part of the year. This also agrees with the results of a field study by Flores (2014) where eggs were observed in both wet and dry season.

The snail hunters gave out 24 names of plants when asked which vegetation $H$. daphnis prefers (Table 7). This suggests that $H$. daphnis is not plant species-specific, which coincides with the result of a study by Gujilde (2013) on the habitat specificity of H. daphnis in Lugo, Borbon, North Cebu. Based on Gujilde's results, "lagnog" ("lagnub") and "ipil-ipil" housed the highest number of $H$. daphnis. "Lagnog" is among those mentioned by the snail hunters three times, along with "an-an" and "nangka". Gujilde also found that $H$. daphnis preferred trees over shrubs, which coincided with the list of plants mentioned by the snail hunters, wherein out of the 24 only one was identified as shrub and one identified as vine.

The snail hunters did not give conclusive information on the diet of $H$. daphnis. Any of the following could be the diet of the snails as observed or heard by the snail hunters: leaves of the trees at which they dwell in, bark of trees, morning dew or sap. In a laboratory study done by Montaño (2012) H. daphnis from Cadaruhan and Tabunan, Borbon, Cebu preferred Chromolaena odorata ("hagonoy") and Ficus septica ("agusahis") leaves. However, Montaño's study on the dietary preference of 'takyong' remains inconclusive until further validation since the experimental snails were fed in the laboratory with pre-picked leaves that could have limited the snail's choice of food and may not have emulated the natural environment. Observations of the dietary preference of $H$. daphnis in situ should also be done. In published literature, land snails have a wide range of dietary preference, which includes lichens, earthworms, dead and/or fresh plant material, herbs, grasses, (Boyer, 2013; Parkyn, 2015). 
Human activities observed by snail hunters that could possibly lead to the depletion of the 'takyong' included: overharvesting, gathering juveniles and eggs, as well as destruction of habitat through the cutting of trees in the process of hunting or gathering of fuel wood. The local government should then initiate programs geared towards the prevention of such activities, or if possible, create an ordinance or ordinances that would regulate the harvesting of the snails taking into consideration the snail's life cycle, gears and methods used in harvesting, and the protection of snail habitats, much like what the Bureau of Fisheries and Aquatic Resources in the Philippines is doing in regulating the catching of fish. For example, snail hunters can only harvest snails of a particular size range. Anyone caught disobeying can be fined or sanctioned.

\section{Conclusion}

The physicochemical parameters varied across sites in the dry season. In the wet season, all physicochemical parameters varied significantly across sites except for relative humidity. Abundance, together with relative humidity and air temperature, were significantly higher in the dry season compared to the wet season. This could mean that relative humidity and air temperature are major predictors for $H$. daphnis abundance. Adult $H$. daphnis abundance and total abundance varied significantly across sites only in the dry season. The marked difference in abundance between Site 1 (highest abundance) and Site 2 (lowest abundance) could be due to variations in some of the physicochemical, biological and social factors. Highest relative humidity was recorded at Site 1, and lowest at Site 2. Accessibility to the sites could be another contributor to the difference in snail abundance. Site 1 is privately owned so that harvesting is limited in this area. Site 2 on the other hand, was on a government-owned lot along the highway, hence, more snail hunters could access the area. Another contributing factor could be the harvesting practice of snail hunters. Snail hunters preferred to hunt snails during the wet season. Adult abundance and total abundance were positively correlated with air temperature and relative humidity at Site 1. This further validates the observation that air temperature and relative humidity are major predictors for the snail abundance in this study. Neonate abundance and eggs showed a positive correlation to soil calcium in Site 1, an indication that calcium is necessary for the development of the eggs, and the growth and thickening of the shells of young snails. $H$. daphnis were sold at an average of Php1.00 (0.020 USD), which snail hunters thought to be too cheap considering the effort and energy consumed in hunting the snails. There are currently no existing government programs in the study areas for the protection of $H$. daphnis, but snail hunters suggested that a program limiting the harvesting of this common resource should be created. Local knowledge on the medicinal effect, life cycle, vegetative preference, and diet coincided with what are found in literature, but extensive studies are still needed to be done to further validate this knowledge and to know more about the snails. Human activities, which seemed to affect the population of snails, according to local knowledge, were overharvesting and habitat destruction.

\section{Recommendations}

Based on the results of this study, the researcher suggests the following ordinances/programs to limit/regulate harvesting of 'takyong': 
- Snail hunting should be limited to 'takyong' that are 2 inches in height or longer, and organisms should be available for inspection by Barangay officials.

- Getting of $H$. daphnis eggs should be prevented.

- Cutting of trees, especially those preferred by snails (i.e. 'lagnog', 'tamban', 'anan' and 'nangka'), by snail hunters or by any person should be controlled.

- Activities that would educate children or even adults in the importance of $H$. daphnis in the ecosystem should be done.

- The municipality should designate a sanctuary or sanctuaries for 'takyong.' In these areas, disposal of trash or other materials should be prohibited. Furthermore, disturbance, construction on, or alteration of the vegetation should be prevented. Most importantly, harvesting of $H$. daphnis should not be allowed.

Anyone caught going against these programs/ordinances should appropriately be sanctioned. Implementing rules and regulations should, therefore, be formulated in conjunction with the creation/formulation of conservation programs/ordinances for 'takyong'.

\section{REFERENCES}

[1] Baur, A., Minorette, N., Baur, B. (2009): Effects of Soil Type and adult Size on Mating and Propensity and Reproductive Output in Two Populations of the Land Snail Ariantaarbustorum (Linnaeus). - Malcologia 51(1):1-11.

[2] Bensig, E., Edullantes, B., Narsico, J. (2014): Antibacterial activity of the tissue extracts of Helicostyla daphnis (Takyong). - International Journal of Biosciences 5(3):246-251.

[3] Boyer, S., Wratten, S., Holyoake, W., Abdelkrim, J., Cruickshank, R. (2013): Using Next Generation Sequencing to Analyze the diet of a Highly Endangered Land Snail (Powelliphanta auguta) Feeding on Endemic Earthworms. -PLOS ONE 8 (10): 10

[4] Chukwuka, C.O., Ejere, V., Asogwa, C., Nnamonu, E., Okeke, Odii, E.I; Ugwu, G.C; Okanya, L.C; and Levi, C.A. (2014): Eco-physiological adaptation of land snail Achatina achatina (Gastropoda: Pulmonata) in tropical- agro ecosystem.- The Journal of Basic and Applied Zoology 67(2)-48-57.

[5] Clausnitzer, V., Camberlidge, N. (2012): Spineless.- Zoological Society of London, United Kingdom

[6] Coney, C. (2001): Endangered wildlife and plants of the world. - New York: Marshal Cavendish Company

[7] Davis, A.,Wagner, R. (2003): Who Knows? On the Importance of Identifying "Experts" When Researching Local Ecological Knowledge. -Human Ecology 31:463-489.

[8] de Chavez, E., de Lara, A. (2011): Diversity and spatial distribution patterns of macro landsnails on Mount Makiling Forest Reserve, Philippines.- The Asian International Journal of Life Sciences 20 (1)185-201.

[9] Flores, M. (2014): Abundance and population profile of Helicostyla daphnis (Stylommatophora: Bradybaenidae), an endemic snail of Cebu, Philippines.- Journal of Biodiversity and Environmental Sciences 5(1):477-491.

[10] Garces, R. (2011 March 3): Meet Takyung. Phistar.com. TheFreeman.Web.

[11] Gilbert, K., Long, E., Micha B, and Quinn, R. (2011): Diversity and Abundance of Terrestrial Snails Across an Altitudinal Gradient at Moka, Bioko Island, Equatorial Guinea.- Journal of Molluscan Studies 80(2):161-168.

[12] Gujilde, J. (2013): Habitat specificity of Helicostyla daphnis (Broderip 1841). Bachelor of Science (Biology) Undergraduate Thesis. University of the Philippines Cebu. 
[13] Horsak, M., Zeleny,D., Hajek, M. (2014): Land snail richness and abundance along a sharp ecological gradient at two samplinc scales: disentangling relationships.- Journal of Molluscan Studies. 80 (3): 256-264.

[14] Hottop, K. (2014): Landsnail Ecology. - Carnegie Museum of Natural History.

[15] Hunter, R. (2013): Physiology of Mollusca. - The Mollusca Elsevier.

[16] IUCN (2016): The IUCN Red List of Threatened Species. Version 2016-3.

[17] Johnson, M. (2011): Effects of Contrasting Habitats and the weather on the abundance of the Land Snail Theba Pisana (o.f. Muller, 1774): A 34-year study.- Journal of Molluscan Studies 77:218-225.

[18] Montaño, M. (2012): Leaf Preference of Terrestrial Snail Helicostyla daphnis from Cadaruhan and Tabunan, Borbon, Cebu. Bachelor of Science (Biology) Undergraduate Thesis. University of the Philippines Cebu.

[19] Moreno-Rueda, G. (2014): Distribution of arid-dwelling land snails according to dryness.- Journal of Arid Environments 103: 8-84.

[20] Nunes, G., Santos, S. (2012): Environmental factors affecting the distribution of land snails in the Atlantic Rain Forest of Ilha Grande, Angra dos Reis, RJ, Brazil.- Brazilian Journal of Biology 72(1):79-86.

[21] Parkyn,J., Challisthianagara, A., Brooks, L., Specht, A., McMullan-Fisher, S., Newell, D. (2015): The natural diet of the endangered camaenid land snail Thersites mitchellae (Cox, 1864) in northern New South Wales, Australia.- Australian Zoologist 3(7):343-349.

[22] Pechenik, J. (2014): Biology of Invertebrates. - McGraw-Hull Education, New York, NY 1021.

[23] Pimm, S., Jenkins, C., Abell, R., Brooks, T., Gittleman, J., Joppa, L., Raven, P., Roberts, C., Sexton, O. (2014): The biodiveristy of species and their rates of extinction, distribution, and protection.-Science 344: 6187.

[24] Roda, A., Nachman, G., Weihman, S., Cong, M., Zimmerman, F. (2016): Reproductive Ecology of Giant African Snail in South Florida: Implications for Eradication Programs. PLoS One. 11:11.

[25] Schilthuizen, M., Rutjes, H. (2001): Land snail diversity in a square kilometre of tropical rainforest in Sabah, Malaysian Borneo. - Journal of Molluscan Studies 67:417-423.

[26] Thorp, J., Rogers, C. (2016): Thorp and Covich's Freshwater Invertebrates $4^{\text {th }}$ editionElsevier.

[27] Yeung, N., Hayes, K., Cowie, R. (2013): Effects of Washing Produce Contaminated with the Snail and Slug Hosts of Angiostrongylus cantonensis with Three Common Household Solutions.- Hawaii J Med Public Health 72(6 Suppl 2):83-86. 